\title{
IDENTIFIKASI SENYAWA KIMIA PADA SIMPLISIA DAUN SIRSAK (Annona muricata Linn.)
}

\author{
Mamay Mas lahat ${ }^{1}$. Amry Syaawalz² dan Rahayu Restianingsih? \\ 1. 1) Program Studi Kimia, Fakultas MIPA, Universitas Nusa Bangsa Bogor \\ Ji. Sholch Iskandar KM 4 Cimanggu Tanah Sarcal Bogor, 16166 \\ 3) Laboratorium Kimia Forensik MABES POLRI \\ 1)Email : mavkulsumavahoo,co.id
}

ABSTRACT

\section{Identification of chemical coumpound in Sirsuk Leaves (Annona muricata Linn)}

Sirsak leaves (Annana municata) contain cytotoxic companents against vartous distases. Cytotcade

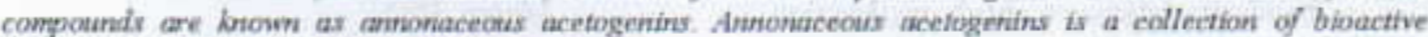
compotunis in the leaves of sirsak are useful as anticancer, antuamor, antiviral, anti - inflammatory. antidepressant, astidiabetic, anticonnalsant, antifacterial and lowering blood pressure. The purpose of this study was to identify the chemical componends contained of sirsak leaf. Research activities inchuled the preparation of crade drug powider sirnak leaves, the determination of the water cantent of orude drugs, extraction of cruile drugs with ethanal solwnts, sepanation of fianonoids using the technique of thin layer clommatogriphy (7LC). Phytochemical tests an the cride chugs and extructs of ethanol and identification of chemical campormds separation results using UV spectrophotometer isstuments and FTIR speco-ophotometer. The results showed that the ethand exmact and crade drag powder of sirsak leaves were positive contain alkalotds, flavonoids, steroids briterpenoids, tanins and saponins. TLC stpanation of the ethamol extract were observed uring UV laght at $\lambda .254 \mathrm{~nm}$ prodices 1 spot with a value of returdation fictor $(R \mathrm{f})$ of 0.7 dark violet color, indicating she presence of flavanoid sompounds. The results of identificatian by $U V$ spectrophotometer, absorption occured at the maxumam $\lambda 205 \mathrm{~nm}, 260 \mathrm{~nm}$ and $380 \mathrm{~nm}$, which indicated that the compounds fiavonots ( 3 - OH - free). FIIR spectnopliatameter analysis showed the presence of fanctional grotps $-\mathrm{OH}, \mathrm{C}=\mathrm{C}$ and $\mathrm{C}-\mathrm{O}$ in the bentene ring. Keywands: Phytochemistry, otide dnig ponder. Ammong maricata Linn UV spechtrophotometer, FTIR
ppecherophotometer

ABSTRAK

Dum sirsak mengandung komponen sitotoksik (zat racun) terhadap berbagai penyalat. Senyawn sitotoksik dikemal dengan istilah umnonaceous asetogentins. Ammonscsous acetogenins menupakan kumpulan senyawa bioaktif di dalam daun sirsak yang bermanfaat sebagai antikanker, antitumor, antivinus, anti-inflamasi, antidepresi, antidiabetes, antikejang, antibakter dan penurun tekanun darah. Tujuan peneintian ini adaiah untuk: mengidentifikasi sanyawa kimia yang terkandung dalam simplisia daun sirsak (Amnona nuericata Limn). Kegiatan penelitian meliputi pernbuatan serbuk simplisia daun sirsak, penetapan kadar air simplisia, ekstraksi simplisia dengan etanol serta penisahan senyawa flavonoid mengnanakan teknik kromatografi lapis tipis (KLT), uii fitokimia pach simplisia dan tkstnk etanol, serte identifikasi senyawa kimia lasil penisahan menggunakan instrumen spelatrofotometer UV dan spektrofotometer FTIR. Berdasarkan hasil penditian diketahui bahwa serbuk simplisia dan elsstruk etanol dum sirsak positif mengandemg senyawa alkaloid, flavonoid steroid triterpencid, tanin dan saponin. Hasil permisahan KLT terhadap ekstrak etand daun sirsak yang diamati menggunakan sinar UV pada 2.254 ntn menghasilkan I spot dergan nilai retardasi fiktor (Rf) sebesar 0,7 berwarma lembaymg gelap, monunjukkan adanya senyawa flavonoid. Hasil identifikasi dengan spcktrofotometer UV, tarjadi serapan pada $\lambda$ maksimal $205 \mathrm{rm}, 260 \mathrm{~mm}$ dan $380 \mathrm{~mm}$, yang yang menumjukan sernyawa flavond (3- OH betas). Analisis spelitrofotometer FTIR merninjukkan adanya gugus fingxi - $\mathrm{OH}, \mathrm{C}=\mathrm{C}$ dan $\mathrm{C}-\mathrm{O}$ pada cincin benzena

Kata kunei : fitokimia, simplisia, Antona merketa Linn., spektrum UV, spektrum Infia Red. 


\section{PENDAHULUAN}

Metabolit sekunder yang terkandung pada tanaman dapat berupa senyawa kimia alkaloid, flavonoid, terpenoid dan steroid. Metabolit sekunder pada tanaman diduga merupakan senyawa bioaktif yang menyebabkan tanaman ini berkhasiat sebagai obat (Harborne, 1987).

Senyawa bermanfaat pada tanaman sirsak bukan hanya terletak pada buahnya. Hampir seluruh bagian pohon sirsak memiliki khasiat yang luar biasa. Bagian yang paling bermanfaat ada di dalam daunnya. Daun sirsak mengandung komponen sitotoksik (zat racun) terhadap berbagai penyakit. Senyawa sitotoksik tersubut akrab disebut annonaceous acelogenins. Annonaceous acetogenins merupakan kumpulan senyawa bioaktif di dalam daun sirsak yang bermanfaat sebagai antikanker, antitumor, antivirus, anti-inflamasi, antidepresi, antidiabetes, antikcjang, antibakteri dan penurun tekanan darah (Zuhud, 2011).

Hasil penelitian scbelumnya menyatakan bahwa daun sirsak juga mengandung senyawa flavonoid. Isolasi flavonoid dilakukan dengan metode Charaux-Paris yaitu elstraksi bertahap dengan menggunakan beberapa pelarut yang berbeda kepolarannya, yaitu nheksana, kloroform, etil asetat dan $\mathrm{n}$ butanol. Dari fase - fase ekstraksi yang diperoleh, hanya fase etil asetat dan fase nbutanol yang mengandung senyawa flavonoid (Asih, 1992). Senyawa senyawa yang mempunyai potensi sebagai antioksidan umumnya merupakan senyawa flavonoid, fenolat dan alkaloid. Senyawa flavonoid dan polifenolat bersifat antioksidan, antidiabetik, antikanker, antiseptik dan anti-inflamasi, sedangkan senyawa alkaloid mempunyai sifat antineoplastik yang juga ampuh menghambat pertumbuhan sel - sel kanker (Sadewo, 2005).

Spektrofotometer UV dapat
digunakan untuk membantu
mengidentifikasi jenis flavonoid dan
menentukan pola oksigenasi. Di samping
itu, kedudukan gugus hidroksil fenol bebas
pada inti flavonoid dapat ditentukan

dengan menambahkan pereaksi diagnostik ke dalam larutan cuplikan dan mengamati pergeseran puneak serapan yang terjadi. Dengan demikian, secara tidak langsung cara ini berguna untuk menentukan kedudukan gula atau metal yang terikat pada salah satu gugus hidroksi fenol (Markham, 1988), Selain spektrofotometer UV, spektrofotometer infra Red (IR) dapat digunakan pula untuk mengidentifikasi senyawa organik. Spektrum infra merah dari senyawa organik mempunyai sifat fisik yang karakteristik artinya kemungkinan dua senyawa mempunyai spcktrum yang sama adalah kecil sckali. Spektrum peresapan IR merupakan perubahan simultan dari energi vibrasi dan energi rotasi dari suatu molekul. Kebanyakan molekul organik cukup bekar sehingga spektrum peresapannya kompleks.

Tujuan penelitian ini adalah untuk mengidentifikasi senyawa kimia yang terkandung dalam simplisia daun sirsak (Ammona muricata Linn.)

\section{METODE PENELITIAN}

\section{Bahan dan Alat}

Bahan yang digunakan antara lain daun sirsak (Annona nuricata Linn.) yang berasal dari kebun budidaya Biofarmaka, Institut Pertanian Bogor (IPB), ctanol 95\%, heksana, HCL p.a., KOH flake, kloroform, metanol, n-butanol, n-propanol, asam asetat, etil asetat, piridin, ammonia $25 \%$, $\mathrm{HCl} 37 \%$ pereaksi Dragendorf, pereaksi Liebermann-Buchard, serbuk magnesium. amil alkohol, $\mathrm{FeCl}, 1 \%$ dietil eter, lempeng kromatografi lapis tipis (KLT) silika gel GF254 dan akuades.

Peralatan yang digunakan adalah oven, blender, ayakan mesh 60 , timbangan analitik (Mettler Toledo XS205 DU), rotary evaporator, corong pisah, peralatan gelas, peralatan KLT, lampu UV, Spektrofotometer UV 8453 merk Agilent, Spektrofotometer FTIR portable merk Thermo Fisher. 


\section{Prosedur Kerja}

\section{Preparasi Simplisia}

Daun sirsak yang digunakan berasal dari pohon sirsak yang pernah berbuah agar kandungan zat kimianya lebih lengkap. Daun sirsak yang diambil tidak terlalu muda atan tidak terlalu tua, yaitu daun $\mathrm{ke}-4$ dan $\mathrm{ke}-5$ dari satu ranting (Zuhud, 2011).

Daun sirsak segar dibersihkan dari kotoran - kotoran yang menempel, dicuci dengan air hingga bersih, kemudian ditiriskan untuk membebaskan daun dari sisa air cucian. Daun dikeringkan dengan bantuan sinar matahari tetapi tidak secara langsung, cukup dengan cara diangin - anginkan. Selanjutnya daum sirsak kering digiling sehingga menjadi simplisia serbuk, lalu diayak dengan mesh 60. Simplisia disimpan dalam wadah bersih dan ditutup (Depkes, 1985).

\section{Penetapan Kadar Air Simplisia}

Cawan porselin kosong dikeringkan pada suhu $105^{\circ} \mathrm{C}$ selama 1 jam. Kemudian didinginkan dalam eksikator lalu ditimbang. Sampel sebanyak $2 \mathrm{~g}$ dimasukkan ke dalam cawan dan ditimbang dan dicatat, kemudian cawan berisi sampel dimasukkan ke dalam oven pada suhu $105{ }^{\circ} \mathrm{C}$ hingga mencapai bobot yang konstan. Kemudian didinginkan, dimasukkan dalam eksikator selama 15 menit dan ditimbang dengan teliti dan dicatat. Kadar air dihitung. Kadar air dilakukan triplo.

$$
\text { Kadar air (\%) }=\frac{\text { Kehilangan Bobot }(\mathrm{g})}{\text { Bobot Contoh }(g)} \times 100 \%
$$

\section{Ekstraksi Simplisia}

Proses ekstraksi dilakukan dengan metode maserasi Simplisia serbuk sebanyak 400 gram dimaserasi dengan etanol $95 \%$. Campuran simplisia dan pelarut direndam selama 6 jam dengan sesckali diaduk, kemudian dibiarkan selama 24 jam pada suhu kamar. Setelah proses maserasi selesai campuran disaring dengan kertas saring Whatman 42, lalu filtrat disimpan pada wadah tertutup, sodangkan ampas dimaserasi kembali dengan etanol $95 \%$ dengan prosedur yang sama. Kemudian filtrat diuapkan sampai volumenya sisa $1 / 3$ volume awal.

\section{Uji Fitokimia}

Sampel serbuk simplisia yang digunakan pada uji fitokimia sebanyak 2 gram dan sampel ekstrak etanol sebanyak 0,2 gram.

\section{A. Identifikasi Golongan Alkaloid}

Sampel ditambahkan $5 \mathrm{ml}$ ammonia $25 \%$ lalu digerus dengan lumpang. Ditambahkan $20 \mathrm{ml}$ kloroform, digerus kembali, lalu disaring. Filtrat dimasukkan ke dalam tabung reaksi, ditambahkan $\mathrm{HCl} 10 \%$, lalu dikocok. Diambil larutan bagian atas (fasa kloroform), lalu ditambahkan pereaksi Dragendorf. Apabila terbentuk endapan merah bata dengan pereaksi Dragendorf menunjukkan adanya senyawa golongan alkaloid.

\section{B. Identifikasi Golongan Flavonoid}

Sampel sebanyak 0,2 gram ditambahkan $100 \mathrm{ml}$ air panas, dididihkan selama 5 menit. lalu disaring dengan kertas saring (larutan A). Sebanyak $5 \mathrm{ml}$ larutan A dimasukkan ke dalam tabung reaksi, ditambahkan serbuk magnesium sebanyak 0,1 gram, $1 \mathrm{ml} \mathrm{HCl}$ pekat dan $5 \mathrm{ml}$ amil alkohol, lalu dikocok dengan kuat dan dibiarkan hingga memisah. Terbentuknya warna merah, kuning atau jingga pada lapisan amil alkohol 
memunjukkan adanya senyawa golongan flavonoid.

\section{Identifikasi Golongan Saponin}

Lanutan A sebanyak $10 \mathrm{ml}$ dimasukkan ke dalam tabung reaksi dan dikocok dengan kuat selama 10 monit. Terbentuknya busa yang stabil dalam tabung reaksi menunjukkan adanya senyawa golongan saponin, bila ditambahkan 1 tetes $\mathrm{HCl} 1 \%$, busa tetap stabil.

\section{Identifikasi Golongan Tanin}

Larutan A sebanyak $50 \mathrm{ml}$ dimasukkan ke dalam erlenmeyer 100 $\mathrm{ml}$, lalu ditambahkan $\mathrm{FeCl}_{3} 1 \%$. Terbentuknya wama biru tua atau hijau kehitaman menunjukkan adanya senyawa golongan tanin.

\section{E. Identifikasi Golongan Steroid dan Triterpenoid}

Sampel dimasukkan ke dalam erlenmeyer tertutup asah, ditambahkan $20 \mathrm{ml}$ dietileter, dimaserasi selama 2 jam lalu disaring. Sebanyak $5 \mathrm{ml}$ filtrat diuapkan dalam cawan hingga diperoleh residu, Ialu ditambahkan pereaksi Liebermann-Buchard. Terbentuknya warna merah atau hijau menunjukkan adanya senyawa golongan steroid atau triterpenoid.

\section{F, Identifikasi Senyawa kimia Flavonoid}

Filtrat etanol $95 \%$ ditambahkan heksana dengan perbandingan $1: 2$ Kemudian larutan tersebut diekstraksi dengan $\mathrm{HCl} 0,1 \mathrm{~N}$ sebanyak 3 kali menggunakan corong pisah. Lapisan $\mathrm{HCl}$ dan lapisan heksana dipisahkan. Lapisan heksana diekstrak dengan $\mathrm{KOH} 0,1 \mathrm{~N}$ sebanyak 3 kali. Lapisan $\mathrm{KOH}$ dan lapisan heksana dipisahkan. Iapisan $\mathrm{KOH}$ lalu dinetralkan dengan $\mathrm{HCl} 0,1 \mathrm{~N}$. Lantan ini kemudian diekstrak dengan kloroform sebanyak 3 kali lalu dipisahkan. Lapisan kloroform air diuji fitokimia. Lapisan kloroform ini yang diduga mengandung senyawa flavonoid. Lapisan kloroform balu ditotolkan pada plat kromatografi lapis tipis silika gel. Fase gerak yang optimal dicari dengan menggunakan campuran bebcrapa pelarut. Fase gerak yang digunakan yaitu n-heksana : n-propanol $(100: 1)$, n-heksana : metanol $(100: 1)$; $\mathrm{n}^{-}$ butanol : asam asetat : air $(4: 1: 5)$ dan etil asetat : piridin : air : metanol $(80: 20: 10$ : 5). Fase gerak yang optimal yaitu nbutanol : asam asetat:air $(4: 1 ; 5)$ dicampur dalam corong pemisah, yang dipakai fase atasnya dengan waktu penjenuhan 17 jam. Noda pemisahan dideteksi di bawah lampu UV $254 \mathrm{~nm}$ dan diuapi dengan uap ammonia lalu dideteksi lagi di bawah lampu UV $254 \mathrm{~mm}$. Noda dengan Rf yang sama dikumpulkan kemudian dilarutkan dengan metanol. Masing - masing fraksi diidentifikasi dengan Spektrofotometer UV dan FTIR.

\section{HASIL DAN PEMBAHASAN}

\section{Penetapan Kadar Air Simplisia}

Sampel yang digunakan pada penelitian ini merupakan bahan yang berasal dari tumbuh - tumbuhan, schingga sampel mengandung air dalam jumlah relatif tinggi. Oleh karena itu, penentuan kadar air harus dilakukan, karena akan mempengaruhi daya tahan bahan pangan terhadap aktivitas atau serangan mikroorganisme. Kadar air ditetapkan dengan cara gravimetri, yaitu diperoleh dengan cara menghitung bobot bahan sebelum dan sesudah dikeringkan pada temperatur di atas titik didih air, sehingga diharapkan semua air akan menguap pada suhu tersebut dan pada periode tertentu. Air yang terkandung dalam serbuk daun sirsak dihilangkan dengan pemanasan pada suhu $105^{\circ} \mathrm{C}$. Menurut Harjadi (1993), air yang terikat secara fisik dapat dihilangkan dengan pemanasan pada suhu $100-105^{\circ} \mathrm{C}$. Standar kadar air untuk 
simplisia adalah kurang dari $10 \%$ (Depkes RI, 1985). Kadar air rata-rata sampel serbuk daun sirsak yang diperoleh pada penelitian ini disajikan pada Tabel 4 yaitu sebesar $4,43 \%$

\section{Ekstraksi Simplisia}

Simplisia daun sirsak dimaserasi menggunakan pelarut etanol 95\%. Proses maserasi merupakan metode ckstraksi yang paling sederhana dan peralatan yang digunakan sederhana. Jika menggunakan metode ekstraksi dengan suhu yang terlalu tinggi, dikhawatirkan potensi senyawa aktif akan rusak.

Pelarut etanol digunakan karena ctanol merupakan pelarut yang baik. memiliki sifat kepolaran yang moderat dengan nilai indeks polaritas 24,30. Setelah proses maserasi, filtrat etanol dipekatkan sampai volumenya tersisa $1 / 3$ volume awal dengan menggunakan alat rotary exaporator. Ekstrak etanol yang dihasilkan sebanyak $350 \mathrm{ml}$.

\section{Uji Fitokimia}

Uji fitokimia merupakan uji kimia kualitatif yang dilakukan sebagai uji pendahuuluan untuk mengetahui golongan senyawa metabolit sckunder apa saja yang terdapat pada suatu sampel, dalam hal ini pada serbuk simplisia dan filtrat etanol 95\%. Pengujian ini dilakukan dengan menggunakan pereaksi spesifik untuk setiap golongan senyawa yang akan diuji. $\mathrm{Uji}_{\mathrm{ji}}$ fitokimia ini didasarkan pada identifikasi warna dan/atau endapan yang terbentuk. $\mathrm{Uji}_{\mathrm{ji}}$ fitokimia yang dilakukan meliputi, identifikasi senyawa golongan alkaloid, flavonoid, saponin, tanin, serta steroid dan triterpenoid. Uji fitokimia dilakukan terhadap sampel serbuk daun sirsak dan ekstrak etanol. Hasil uji fitokimia dapat dilihat pada Tabel 2

Tabel 1. Kadar Air Sampel Serbuk Daun Sirsak

\begin{tabular}{clllll} 
Ulangan & $\begin{array}{l}\text { Bobot cawan } \\
\text { kosong }(\mathrm{Pg})\end{array}$ & $\begin{array}{l}\text { Bobot } \\
+ \text { sampel }(\mathrm{g})\end{array}$ & $\begin{array}{l}\text { cawan } \\
(\mathrm{g})\end{array}$ & $\begin{array}{l}\text { Bobot akhir } \\
(\mathrm{g})\end{array}$ & $\begin{array}{l}\text { Kadar Air } \\
(\%)\end{array}$ \\
\hline 1 & 37,5587 & 39,5619 & 2,0032 & 1,9124 & 4,53 \\
2 & 38,4634 & 40,4646 & 2,0012 & 1,9148 & 4,32 \\
\hline Rata - rata & & & & 4,43 \\
\hline
\end{tabular}

Tabel 2. Uji Fitokimia terhadap Serbuk Daun Sirsak dan Ekstrak Etanol

\begin{tabular}{ccc}
\hline Golongan Senyawa & Serbuk Daun Sirsak & Ekstrak Etanol \\
Metabolit Sekunder & + & + \\
\hline Alkaloid & + & + \\
Flavonoid & + & + \\
Steroid/ Triterpenoid & + & + \\
Saponin & + & + \\
Tanin & & + \\
\hline
\end{tabular}

Keterangan : + = hasil uji positif 
Tabel 2 menunjukkan bahwa seluruh senyawa metabolit sekunder yang ada dalam serbuk daun sirsak dan ekstrak etanol, semuanya teridentifikasi positif. Hasil uji dapat dilihat pada Gambar 1 . Pada uji flavonoid simplisia dan ekstrak ctanol menunjukan hasil yang positif, yaitu terbentuknya warna kuning atau merah pada lapisan amil alkohol. $\mathrm{Hal}$ ini menunjukan bahwa sampel mengandung flavonoid (Harbome, 1987). Pada uji flavonoid dilakukan penambahan serbuk $\mathrm{Mg}$, $\mathrm{HCl}$ pekat dan amil alkohol. Magnesium mudah larut dalam suasana asam dan menghasilkan kation bivalen $\mathrm{Mg}^{2+}$ serta gas hidrogen. Adanya gas hidrogen dapat dibuktikan ketika penambahan asam klorida pekat ke dalam larutan dan serbuk magnesium, muncul busa atau gelembung pada campuran. Hal ini dapat dilihat dari persamaan reaksi berikut :

$\mathrm{Mg}+2 \mathrm{H}^{+} \rightarrow \mathrm{Mg}^{2+}+\mathrm{H}_{2} \uparrow$

Ion magnesium ini akan berikatan dengan senyawa flavonoid yang terdapat pada ekstrak etanol sehingga muneul larutan yang berwama. Persamaan reaksi dari uji flavonoid tersebut ditunjukkan pada Gambar 2.

Suatu flavonoid akan menghasilkan garam benzopirilium yang berwama bila direaksikan dengan asam mineral dalam alkohol. Sebagai contoh flavon atau flavonol direaksikan dengan asam mineral akan menghasilkan garam flavilium atau antosianidin yang berwarna. Reaksi yang terjadi dapat dilihat pada Gambar 3.

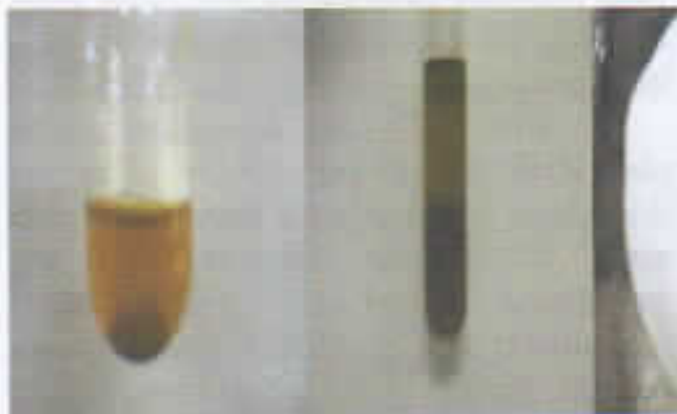

(a) (b)

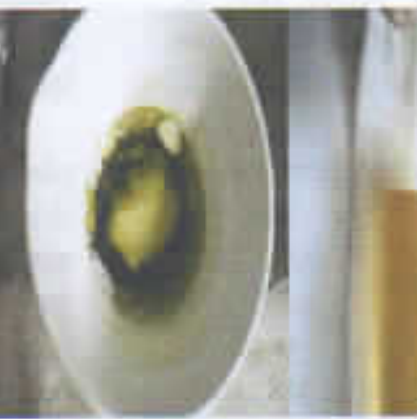

(c)

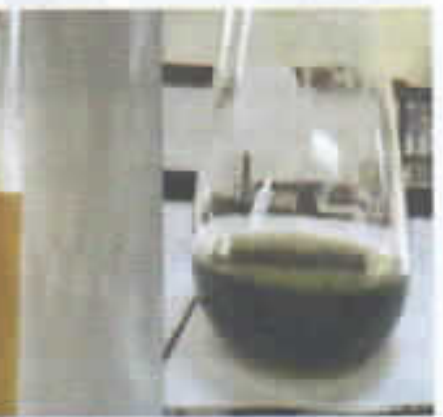

(d) (c)

Gambar 1. Hasil Uji Fitokimia pada Serbuk Daun Sirsak

Keterangan : (a) uji alkaloid

(b) uji flavonoid

(c) uji steroid/triterpenoid

(d) uji saponin

(e) uji tanin<smiles>COc1cc(O)c2c(c1)OC(c1ccc(O)cc1O)CC2=O</smiles>

Gambar 2. Reaksi Identifikasi Flavonoid (Achmad, 1986) 
Tabel 2 menunjukkan bahwa seluruh senyawa metabolit sekunder yang ada dalam serbuk daun sirsak dan ekstrak etanol, scmuanya teridentifikasi positif. Hasil uji dapat dilihat pada Gambar 1 . Pada uji flavonoid simplisia dan ekstrak ctanol menunjukan hasil yang positif, yaitu terbentuknya warna kuning atau merah pada lapisan amil alkohol. Hal ini menunjukan bahwa sampel mengandung flavonoid (Harbome, 1987). Pada uji flavonoid dilakukan penambahan serbuk $\mathrm{Mg}$. $\mathrm{HCl}$ pekat dan amil alkohol. Magnesium mudah larut dalam suasana asam dan menghasilkan kation bivalen $\mathrm{Mg}^{2+}$ serta gas hidrogen. Adanya gas hidrogen dapat dibuktikan ketika penambahan asam klorida pekat ke dalam larutan dan serbuk magnesium, muncul busa atau gelembung pada campuran. $\mathrm{Hal}$ ini dapat dilihat dari persamaan reaksi berikut :

$\mathrm{Mg}+2 \mathrm{H}^{+} \longrightarrow \mathrm{Mg}^{2+}+\mathrm{H}_{2} \uparrow$

Ion magnesium ini akan berikatan dengan senyawa flavonoid yang terdapat pada ekstrak etanol sehingga muneul larutan yang berwama. Persamaan reaksi dari uji flavonoid tersebut ditunjukkan pada Gambar 2.

Suatu flavonoid akan menghasilkan garam benzopirilium yang berwama bila direaksikan dengan asam mineral dalam alkohol. Sebagai contoh flavon atau flavonol direaksikan dengan asam mineral akan menghasilkan garam flavilium atau antosianidin yang berwarna. Reaksi yang terjadi dapat dilihat pada Gambar 3.

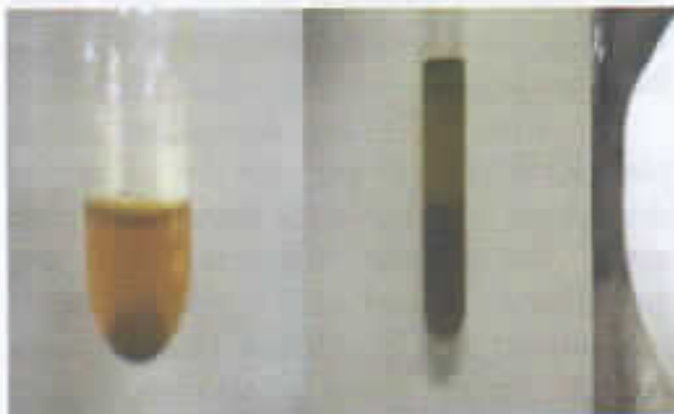

(a) (b)

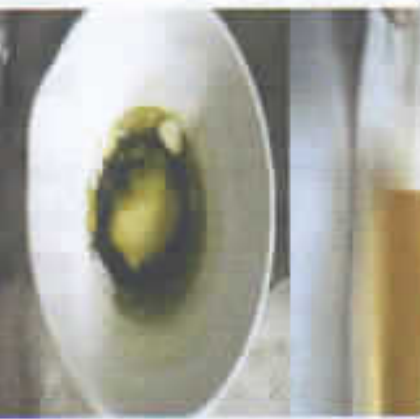

(c)

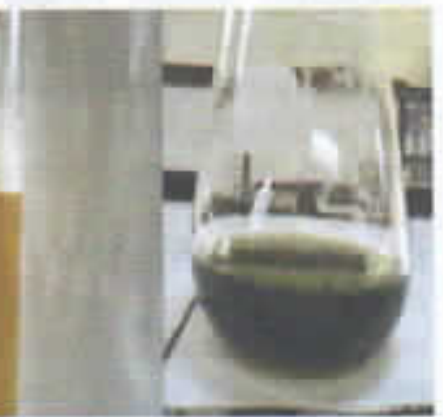

(d)

(e)

Gambar 1. Hasil Uji Fitokimia pada Serbuk Daun Sirsak

Keterangan : (a) uji alkaloid

(b) uji flavonoid

(c) uji steroid/triterpenoid

(d) uji saponin

(e) uji tanin<smiles>COc1cc(O)c2c(c1)OC(c1ccc(O)cc1O)CC2=O</smiles>

Gambar 2. Reaksi Identifikasi Flavonoid (Achmad, 1986) 
<smiles>O=c1c(O)c(-c2ccc(O)c(O)c2)oc2cc(O)cc(O)c12</smiles>

Gambar 3. Reaksi Pembentukan Garam Flavilium (Achmad, 1986)

\section{Identifikasi Senyawa Flavonoid}

Filtrat etanol ditambahkan heksana lalu diekstrak dengan larutan $\mathrm{HCl} 0,1 \mathrm{~N}$. Pengekstrakan dengan $\mathrm{HCl}$ ini bertujuan untuk memisahkan senyawa bersifat basa misalnya alkaloid. Lapisan heksana diekstraksi dengan larutan $\mathrm{KOH} 0,1 \mathrm{~N}$. Pengekstrakan dengan $\mathrm{KOH}$ bertujuan untuk memisahkan senyawa yang bersifat asam, yang dalam hal ini senyawa flavonoid. Senyawa netral seperti lipid berada pada lapisan heksana. Lapisan $\mathrm{KOH}$ dinetralkan dengan $\mathrm{HCl}$ lalu diekstrak dengan kloroform. Pada saat pemisahan lapisan kloroform, terdapat endapan putih kental yang sulit disaring. Hal ini karena masih adanya air yang terdapat pada lapisan kloroform. Natrium sulfat anhidrat ditambahkan ke dalamnya selama 24 jam agar dapat menarik atau mengikat air yang ada pada lapisan kloroform. Sampel filtrat kloroform tersebut diuji flavonoid dengan penambahan serbuk $\mathrm{Mg}, \mathrm{HCl}$ pekat dan amil alkohol. Hasil yang diperoleh yaitu terbentuknya warna kuning pada lapisan amil alkohol. Hal ini menunjukkan bahwa sampel mengandung flavonoid. Filtrat kloroform ini kemudian diidentifikasi dengan teknik kromatografi lapis tipis (KLT).

\section{Analisis Kromatografi Lapis Tipis (KLT)}

Pemisahan senyawa flavonoid dengan teknik KLT menggunakan beberapa eluen campuran diantaranya n- heksana : n-propanol (100:1), n-heksana : metanol $(100: 1)$, n-butanol : asam asetat : air $(4: 1: 5)$ dan ctil asetat : piridin : air : metanol $(80: 20: 10: 5)$ (Markham,1988). Variasi eluen tersebut cukup mewakili kepolaran dari setiap senyawa yang akan dipisahkan, yaitu ada campuran variasi yang berkecenderungan ke arah lebih polar dan ada yang berkecenderungan ke arah lebih nonpolar.

Plat KLT yang digunakan adalah plat KLT silika gel GF254. Plat ini dilengkapi oleh indikator fluoresensi pada sinar UV yang dipasang panjang gelombang emisi 254 nm untuk menampakkan komponen senyawanya sebagai bercak yang gelap atau bercak yang berfluoresensi terang pada dasar yang berfluoresensi seragam. Eluen campuran n butanol : asam asetat : air $(4: 1: 5)$ mampu memberikan pemisahan yang baik daripada eampuran eluen yang lain. Hal ini dapat dilihat dengan adanya noda yang terpisah cukup baik. Noda terpisah berdasarkan kepolarannya. Noda yang mempunyai $R f$ lebih rendah eenderung memiliki kepolaran yang lebih tinggi karena lebih terdistribusi ke fase diam yang bersifat polar, dibandingkan noda yang mempunyai harga $\mathrm{Rf}$ lebih besar karena terdistribusi ke fase gerak. Pada percobaan noda yang dihasilkan hanya 1 buah dan memiliki nilai $\operatorname{Rf}$ sebesar 0,7 . Plat KLT diuapi dengan ammonia untuk meningkatkan kepekaan deteksi dan menghasilkan perubahan warna yang berkaitan dengan senyawa flavonoid. Data penampakan noda dari lapisan kloroform hasil pemisahan dengan KLT disajikan 
pada Tabel 3. Adapun hasil KLT eluen nbutanol : asam asetat : air $(4: 1: 5)$ dan jenis flavonoid yang mungkin disajikan dalam Gambar 4 dan Tabel 4. Pada Gambar 4 banyaknya noda terscbut adalah ulangan sebanyak 6 kali untuk mendapatkan jumlah ckstrak hasil pemisahan yang cukup untuk analisis berikutnya.

Identifikasi dengan Spektrofotometer UV

Noda atau spot hasil KLT yang dideteksi menggunakan sinar UV $254 \mathrm{~nm}$ dan penambahan uap ammonia menunjukkan adanya senyawa flavonoid. Noda-noda tersebut dikerok dan dilarutkan dalam pelarut metanol, kemudian diidentifikasi menggunakan spektrofotometer UV, FTIR. Hasil spektrum UV dari hasil KLT dengan pelarut metanol didapatkan 3 buah puncak pada panjang gelombang $205 \mathrm{~nm}, 255 \mathrm{~nm}$ dan $370 \mathrm{~nm}$. Spektrum UV tersebut dapat dilihat pada Gambar 5.

Berdasarkan Tabel 4 rentang spektrum UV, pita II panjang gelombang $250-280 \mathrm{~nm}$ dan pita I panjang gelombang $350-385 \mathrm{~nm}$, jenis flavonoidnya adalah flavonol $(3-\mathrm{OH}$ bebas) (Markham, 1988). Senyawa senyawa yang mempunyai sistem konjugasi dapat menyerap sinar pada daerah UV, semakin panjang sistem konjugasinya maka makin besar panjang gelombang absorbsinya (Harbome, 1987). Panjang gelombang $205 \mathrm{~nm}$ berasal dari benzena. Benzena menyerap dengan kuat pada panjang gelombang $184 \mathrm{~nm}, 202 \mathrm{~nm}$ dan mempunyai sederet panjang gelombang absorpsi antara $230-270 \mathrm{~nm}$ (Fessenden, 1982).

\section{Identifikasi dengan Spektrofotometer FTIR}

Spektrofotometer FTIR digunakan untuk menentukan gugus fungsi suatu senyawa, terutama senyawa organik. Hasil identifikasi dengan menggunakan spektrofotometer FIIR didapatkan spektrum yang disajikan pada Gambar 16. Setiap serapan pada panjang gelombang tertentu menggambarkan adanya suatu gugus fungsi spesifik. Spektrum terdiri dari pita - pita inframerah yang dapat dikelompokkan menurut intensitasnya yaitu kuat, medium dan lemah.

Pada Gambar 6 terlihat bahwa pita lebar kuat pada puncak $3300 \mathrm{~cm}^{-1}$ menunjukkan adanya gugus $\mathrm{O}-\mathrm{H}$ pada alkohol ikatan hidrogen dan fenol. Pada pita $2850-2970 \mathrm{~cm}^{-4}$ menunjukkan adanya regang $\mathrm{C}-\mathrm{H}$ alifatik. Pada pita $1500-1600 \mathrm{~cm}^{-1}$ menunjukkan adanya $\mathrm{C}=$ $C$ cincin aromatik: Adanya ulur C-O ditunjukkan oleh serapan pada bilangan gelombang $1050 \mathrm{~cm}^{-1}$ (Khopkar, 1985). Analisis spektrofotometer FTIR menunjukkan adanya gugus fungsi- $\mathrm{OH}, \mathrm{C}$ $=\mathrm{C}$ dan $\mathrm{C}-\mathrm{O}$ pada eincin benzena. Struktur flavonol juga mempunyai gugus fungsi yang sama dengan hasil yang didapat dari spektrum FTIR.

Tabel 3. Data Penampakan Noda dari Lapisan Kloroform Hasil Pemisahan KLT Menggunakan Lampu UV $254 \mathrm{~mm}$

\begin{tabular}{llll}
\hline No. & \multicolumn{1}{c}{ Variasi Komposisi Eluen } & $\begin{array}{c}\text { Jumlah } \\
\text { Noda }\end{array}$ & \multicolumn{1}{c}{ Keterangan } \\
\hline 1 & n-heksana : n-propanol $(100: 1)$ & - & Tidak terpisah dengan baik \\
2 & n-heksana : metanol $(100: 1)$ & - & Tidak terpisah dengan baik \\
3 & n-butanol : asam asetat : air & Terpisah cukup baik \\
& $\begin{array}{l}(4: 1: 5) \\
\text { ctil asetat : piridin : air : metanol }(80: 20:\end{array}$ & & Tidak terpisah dengan baik, \\
4 & $10: 5)$
\end{tabular}




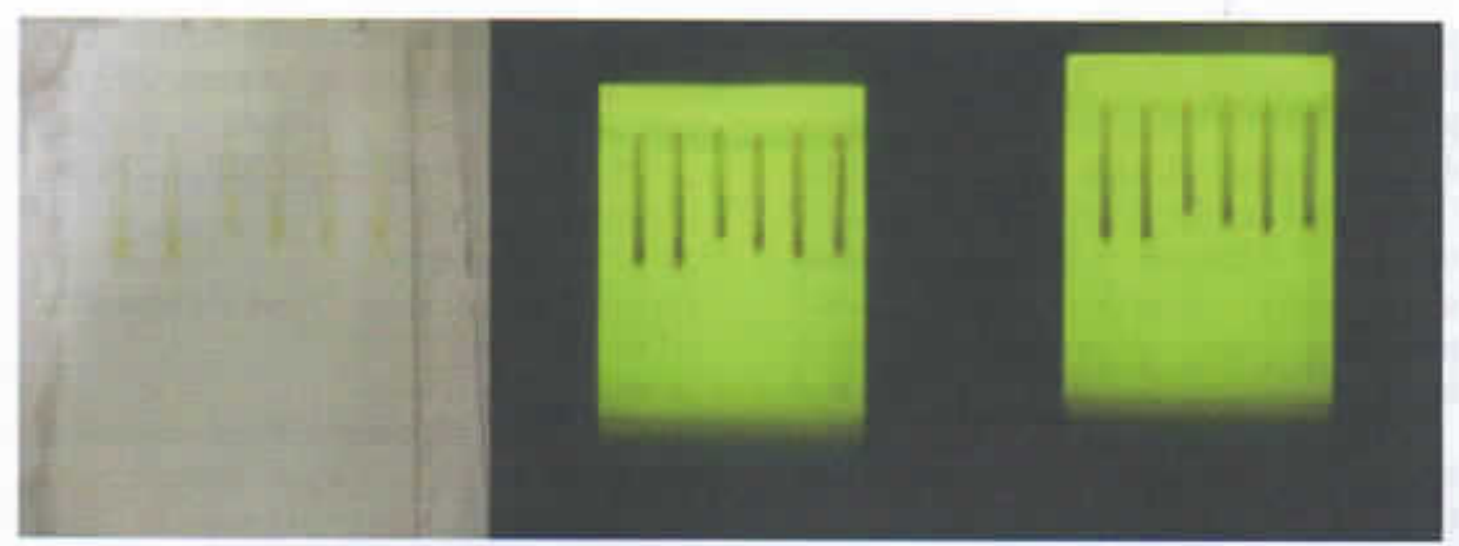

(a)

(b)

(c)

Gambar 4. Foto Plat Hasil KLT dengan Eluen n-Butanol : Asam asetat : Air (4: $1: 5)$

Keterangan : (a) Hasil clusi sebelum diuapi dengan uap ammonia

(b) Hasil pengamatan di bawah sinar UV $2.254 \mathrm{~nm}$ sebelum di uapi dengan uap ammonia

(c) Hasil pengamatan di bawah sinar UV $\lambda 254 \mathrm{~nm}$ setelah diuapi dengan usp ammonia

Tabel 4. Hasil KLT dengan Eluen n-Butanol : Asam asetat : Air $(4: 1: 5)$ di bawah Sinar UV i. $254 \mathrm{~nm}$ dan Jenis Flavonoid yang Mungkin (Markham,1988)

\begin{tabular}{|c|c|c|c|c|}
\hline \multirow{2}{*}{ Rf } & \multirow{2}{*}{$\begin{array}{c}\text { Warna noda } \\
\text { tanpa sinar UV } \\
\text { pada } \lambda .254 \mathrm{~nm}\end{array}$} & \multicolumn{2}{|c|}{$\begin{array}{l}\text { Wama noda di bawah } \\
\text { sinar UV } \lambda 254 \mathrm{~nm}\end{array}$} & \multirow{2}{*}{ Jenis flavonoid yang mungkin } \\
\hline & & Tanpa NHs & $\begin{array}{c}\text { Dengan } \\
\mathrm{NH}_{3}\end{array}$ & \\
\hline \multirow[t]{4}{*}{0.7} & $\underset{\text { kecoklatan }}{\text { Kuning }}$ & $\begin{array}{l}\text { Lembayung } \\
\text { gelap }\end{array}$ & $\begin{array}{l}\text { Lembayung } \\
\text { gelap }\end{array}$ & $\begin{array}{l}\text { a. Biasanya flavon atau flavonol } \\
\text { tersulih pada } 3-O \text { mempunyai } \\
5-\mathrm{OH} \text { tetapi tanpa } 4-\mathrm{OH} \\
\text { bebas. }\end{array}$ \\
\hline & & & & $\begin{array}{l}\text { b. Beberapa 6-atau 8-OH flavon } \\
\text { dan flavonol tersulih pada } 3-0 \\
\text { serta mengandung 5-OH. }\end{array}$ \\
\hline & & & & $\begin{array}{l}\text { c. Isoflavon, dihidro flavonol, } \\
\text { biflavonil, dan beberapa } \\
\text { flavanon yang mengandung 5- } \\
\text { OH. }\end{array}$ \\
\hline & & & & $\begin{array}{l}\text { d. Khalkon yang mengandung } 2 \text { - } \\
\text { atau } 6-\mathrm{OH} \text { tetapi tidak } \\
\text { mengandung 2- atau } 4-\mathrm{OH} \\
\text { bebas. }\end{array}$ \\
\hline
\end{tabular}




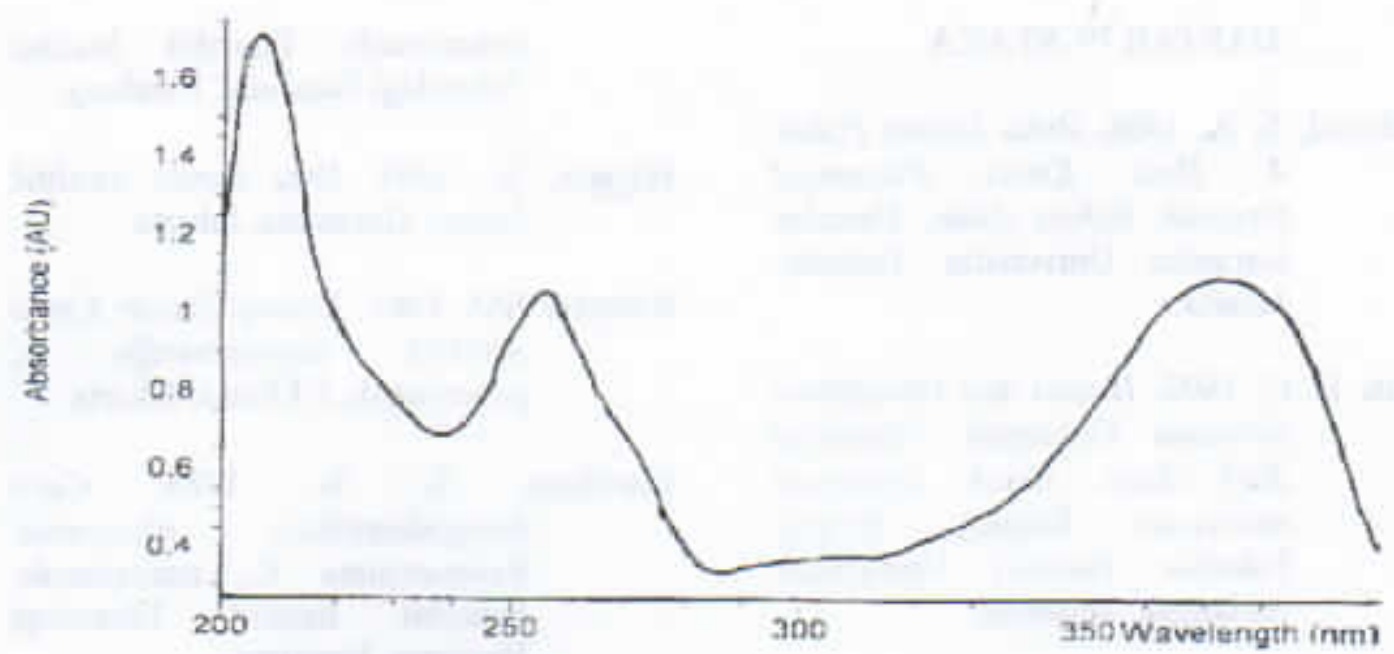

Gambar 5. Pola Spektrum UV Sampel

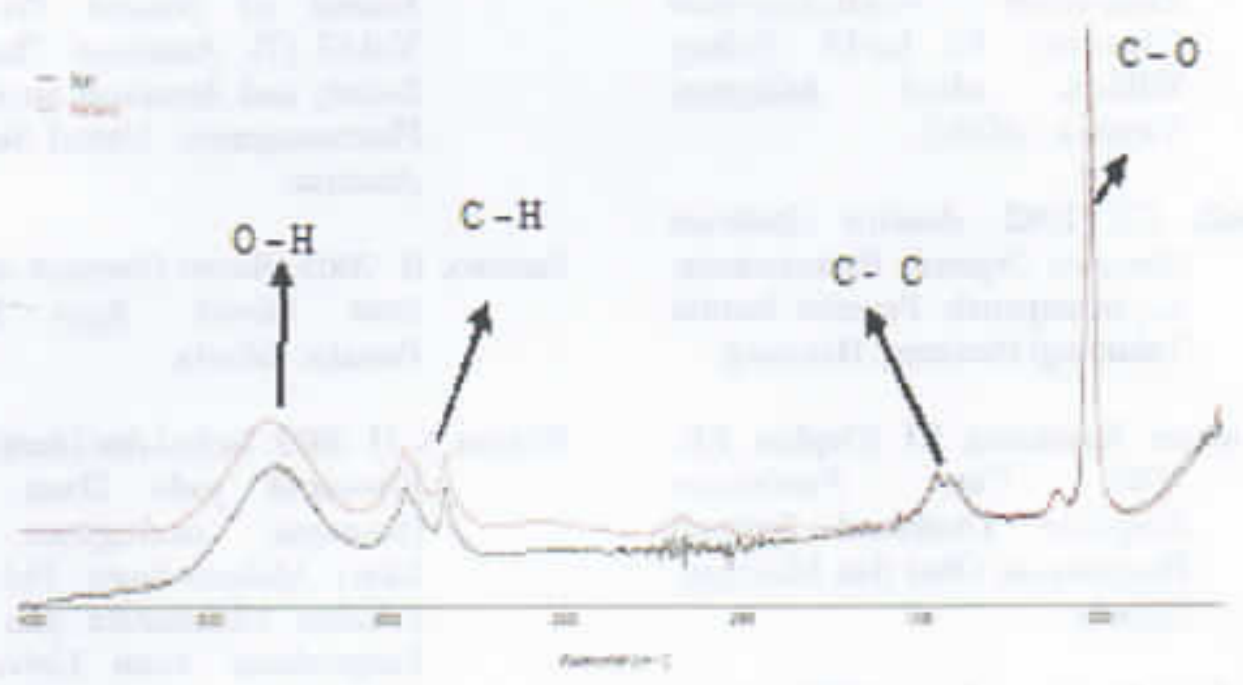

Gambar 6. Pola Spektrum Infra Red Sampel

Keterangan : garis hitam $=$ spektrum sampel garis merah $=$ spektrum hasil pencarian dari library

\section{KESIMPULAN}

Berdasarkan hasil penelitian diketahui bahwa serbuk simplisia dan ckstrak etanol daun sirsak positif mengandung senyawa alkaloid, flavonoid, steroid/triterpenoid, tanin dan saponin. Hasil pernisahan KLT terhadap ekstrak etanol daun sirsak yang diamati menggunakan sinar UV pada $\lambda .254 \mathrm{~nm}$ menghasilkan 1 spot dengan nilai retardasi faktor (Rf) sebesar 0,7 berwama lembayung gelap, menunjukkan adanya senyawa flavonoid. Hasil identifikasi dengan spektrofotometer UV, terjadi serapan pada $\lambda$ maksimal $205 \mathrm{~nm}, 260 \mathrm{~nm}$ dan $380 \mathrm{~nm}$, yang yang menunjukan senyawa flavonol (3-OH bebas). Analisis spektrofotometer FTIR menunjukkan adanya gugus fungsi $-\mathrm{OH}, \mathrm{C}=\mathrm{C}$ dan $\mathrm{C}-\mathrm{O}$ pada cincin benzena. 


\section{DAFTAR PUSTAKA}

Achmad, S. A. 1986. Buku Materi Pokok 4: IImu Kimia Flavonotd Organik Bahan Alam. Penerbit Karunika Universitas Terbuka. Jakarta.

Asih, E. C. 1992 Isolasi dan Identifikasi Senyawa Golongan Flavonotd dari danen sirsak (Annonae muricatae folium), Skripsi. Fakultas Farmasi Universitas Airlangga. Surabaya.

Association of Official Analytical Chemistry (AOAC). 2000. Official Method of Analysis of the Association of Official Analytical Chemistry. Ed ke-17. Sydncy William, editor. Arlington, Virginia : AOAC.

Creswell, CJ. 1982. Analists Spektrum Senyawa Organik. Padmawinata, K., penerjemah. Penerbit Institut Teknologi Bandung. Bandung.

Departemen Kesehatan RI (Depkes RI). 1985. Cara Pembuatan Simpisisia. Direktorat Jenderal Pengawasan Obat dan Makanan. Jakarta.

Fessenden \& Fessenden. 1982. Kimia Organik. Pudjaatmaka, A.H, penerjemah. Erlangga. Jakarta.

Harbornc, J. B. 1987. Metode Fitokimia Cara Modern dan Analisis Tumbuhan. Padmawinata, K., penerjemah. Penerbit Institut Teknologi Bandung. Bandung.

Harjadi, W. 1993. Ilmu Ktmia Analitik Dasar. Gramedia. Jakarta.

Khopkar SM. 1985. Konsep Dasar Kimia Analitik. Saptorahardjo A, penerjemah. UI Press, Jakarta.

Markham, K. R. 1988. Cara Mengidentifikast Flawonoid. Padmawinata, K., penerjemah. Penerbit Institut Teknologi Bandung. Bandung.

Pietta, P., dan Giorgio Pietta. 2000. Flavonoids as Antiaxidants. Journal of Natural Products. Vol.63 (7). American Chemical Society and American Society of Pharmacognosy. United State of America.

Sadewo, B. 2005. Basmi Penyakit dengan Sirth Merah. Agro Media Pustaka. Jakarta.

Wijono, S. H. 2003. Isolasi dan Identifikasi Flavonoid pada Daun Katu (Sauropus androgymus (L.) Merr), Makara Sams. Vol.7 (2). Fakultas Matematika dan Ilmu Pengetahuan Alam Universitas Indonesia. Depok.

Zuhud, A. M. 2011. Bukti Kedahsyatan Sirsak Memumpas Kanker. Agro Media Pustaka. Jakarta. 